\title{
Pediatric patient with diagnosis of extra osseous Ewing's sarcoma of the tongue: case report
}

\author{
Paciente pediátrico com diagnóstico de sarcoma de \\ Ewing extra-ósseo em língua: relato de caso
}

\author{
Neira CHAPARRO ${ }^{1}$ iD 0000-0001-8230-1074 \\ Amaurys DIAZ1 ID 0000-0002-0819-2735 \\ Luis HERRERA ${ }^{1}$ ID 0000-0002-2165-0059 \\ Rafael PINEDA ${ }^{1}$ ID 0000-0001-8511-1954 \\ Betty PEROZO1 ID 0000-0003-0538-5096 \\ Blanca ALVAREZ ${ }^{2}$ iD 0000-0002-3272-2548
}

\begin{abstract}
Ewing's sarcoma is a malignant tumor that arises mainly from bone tissue, so that its extra-osseous presentation is not very common and even more unusual, in the soft tissues of the oral cavity. The objective of this case was to describe the clinical characteristics of an extra-osseous Ewing's Sarcoma of the tongue in a pediatric patient. An 11-year-old male school patient, who attended an oral medicine consultation referring a volume increase in the tongue. Intraorally, a tumoral lesion was observed on the left lateral edge of the tongue, indurated, with the same color of the mucosa with ulcerated areas, well defined edges and symptomatic on palpation, with an approximate size of $2.5 \mathrm{~cm}$. A cervical and maxillofacial MRI was indicated, observing a partially delimited hyperintense and non-infiltrating lesion in the described area. An incisional biopsy was performed with histopathological diagnosis of malignant neoplasm of blue round cells, theCD99 marker was found to be positive in the immunohistochemical study and was key to the definitive diagnosis of this tumor. A thoraco-abdomino-pelvic tomography was requested by the Pediatric Oncology service, as well as biopsy and aspiration of bone marrow, in which no neoplastic infiltrations were evidenced. After four cycles of chemotherapy, total removal of the lesion was performed with a consecutive histopathological study of the surgical piece, indicating free edges of the lesion. Ewing's sarcoma is a tumor with aggressive behavior, so this case represents a finding of clinical and epidemiological relevance, both due to its extra-osseous appearance and its unusual behavior.
\end{abstract}

Indexing terms: Ewing's sarcoma. Mouth. Sarcoma. Tongue.

\section{RESUMO}

O sarcoma de Ewing é um tumor maligno que surge principalmente de tecido ósseo, pelo qual sua apresentação extra-óssea não é muito comum, sendo ainda mais raro seu aparecimento em tecidos moles da cavidade bucal. O objetivo deste caso foi descrever as

\footnotetext{
$\checkmark v \nabla$

1 Universidad del Zulia, Facultad de Odontologia, Instituto de Investigaciones, Area Clínica y Patología. Calle 65, esquina av. 19. Edificio Ciencia y Salud 3er piso. Maracaibo, Zulia, Venezuela. Correspondência para / Correspondence to: N CHAPARRO. E-mail: <neirach@yahoo.com>.

2 Hospital Universitario de Maracaibo, Service, de Odontología, unidad de Cirugía Bucal Y Maxilogacial. Maracaibo, Zulia, Venezuela.

$\boldsymbol{\nabla} \mathbf{v}$

Como citar estar artigo / How to cite this article

Chaparro N, Diaz A, Herrera L, Pineda R, Perozo B, Alvarez B. Pediatric patient with diagnosis of extra osseous Ewing's sarcoma of the tongue: case report. RGO, Rev Gaúch Odontol. 2018;66(4):399-403. http://dx.doi.org/10.1590/1981-8637201800040000153608
} 
características clínicas de um Sarcoma de Ewing extra-ósseo em língua em paciente pediátrico. Refere-se a paciente escolar masculino de 11 anos de idade, quem acudiu a consulta de Medicina Bucal referindo um aumento de volume em língua. Intraoralmente observou-se lesão tumoral em borda lateral esquerda de língua, indurada, da mesma cor da mucosa com áreas ulceradas e bordas bem definidas, de aproximadamente $2,5 \mathrm{~cm}$. Foi indicada uma ressonância magnética cervical e maxilofacial, observando-se uma lesão hiperintensa, parcialmente delimitada e não infiltrante na zona descrita. Realizou-se biópsia incisional com diagnóstico histopatológico de Neoplasia maligna de células redondas azuis, o marcador de imunohistoquímica CD99, encontrado positivo neste caso foi chave para o diagnóstico definitivo. Uma tomografia abdominotorácico-pélvico foi requerida pelo serviço de Oncologia Pediátrica, além de aspirado e biópsia de medula óssea, nos quais não se evidenciaram infiltrações neoplásicas. Após quatro ciclos de quimioterapia, realizou-se a cisão da lesão e consecutivo estudo da peça cirúrgica, indicando bordas livres de lesão. O sarcoma de Ewing é um tumor de comportamento agressivo, pelo qual este caso representa um achado de relevância clínica e epidemiológica, tanto por sua aparição extra-óssea quanto por seu comportamento inusual.

Termos de indexação: Sarcoma de Ewing. Boca. Sarcoma. Língua.

\section{INTRODUCTION}

Ewing's sarcoma (ES) is a rare and highly malignant tumor that may arise from bone and soft tissue. However, it occurs most frequently in bone tissue and comprises about $4 \%$ to $6 \%$ of all primary bone tumors and represents one of the most common bone malignancies after myeloma, osteosarcoma and chondrosarcoma [1]. This family of sarcomas includes the tumor of Askim and both the osseous and extra osseous Ewing's sarcoma [2]. This tumor in all its presentations, affects mainly children and young adults, having an estimated annual incidence of 2.93 cases per million in the population of under 20 years of age, with a predilection for the male sex, and it is ten times more frequent in Caucasian children than in Afro-American ones $[1,3]$.

The presence of Ewing's sarcoma in the oral and maxillofacial region is not very common, accounting for $3 \%$ of all cases. Recent studies have reported that both in the oral cavity and the head and neck region, the mandible is the most frequent location of this tumor being affected in $68 \%$ of cases, followed by the maxilla with $28.2 \%$ and soft tissues with $2.8 \%[3,4]$. The extra osseous presentation of this tumor represents approximately $4 \%$ of soft tissue tumors and $1.5-4 \%$ of childhood sarcomas [4].

The origin of this tumor is still unclear; however, several studies have reported that it comes from neuroectodermal cells. The immature reticular cells, the primitive mesenchymal cells of bone marrow and the existence of a genetic translocation $(11 ; 22)$ (q24; q12) or $(21 ; 22)$ (q22; q12) may seem involved in this tumor's origin. This neoplasm is defined as a soft tissue tumor without bone involvement, with a histology characterized by presenting blue round cells of small size. Its behavior is very aggressive and it has been estimated that metastases are already present at the time of diagnosis in 15-28\% of cases. However, when hidden micrometastases are considered, some publications raise this percentage to $80 \%$.

\section{CASE REPORT}

An 11-year-old male pediatric patient, who attended an Oral Medicine consultation at the Hospital Universitario de Maracaibo, because of a tumoral lesion on the tongue. When performing the extra oral examination, palpable asymptomatic bilateral submandibular lymph nodes were observed with an estimated diameter of 2 $\mathrm{cm}$. Intraorally, a tumoral lesion of approximately 2.5 $\mathrm{cm}$ was found on the left lateral margin of the tongue, with a whitish color with ulcerated areas, well-defined edges, indurated and symptomatic (figure 1). A cervical and maxillofacial MRI was indicated, in which a partially delimited hyperintense lesion was observed in the previously described zone, without apparent infiltration of adjacent structures.

An incisional biopsy of the lesion was performed and a subsequent histopathological study, whose diagnosis indicated a malignant neoplasm of blue round cells (figure 2A). An immunohistochemistry study was necessary for the definitive diagnosis, which indicated Extra osseous Ewing's sarcoma / Primitive neuroectodermal tumor (PNET), immunoreactive to the markers of Vimentin mesenchymal differentiation (figure 2B), neuron-specific neuroendocrineenolase differentiation (NSA) (figure 2C), PGP 9.50 and to the CD99 / MIC-2 marker (figure 2D), while the epithelial, lymphoid and desmin differentiation markers were found to be negative (figure $2 \mathrm{E}, 2 \mathrm{~F}$ ).

In order to determine the presence or absence of neoplastic infiltrations in other parts of the body, complementary imaging studies were performed, such as 


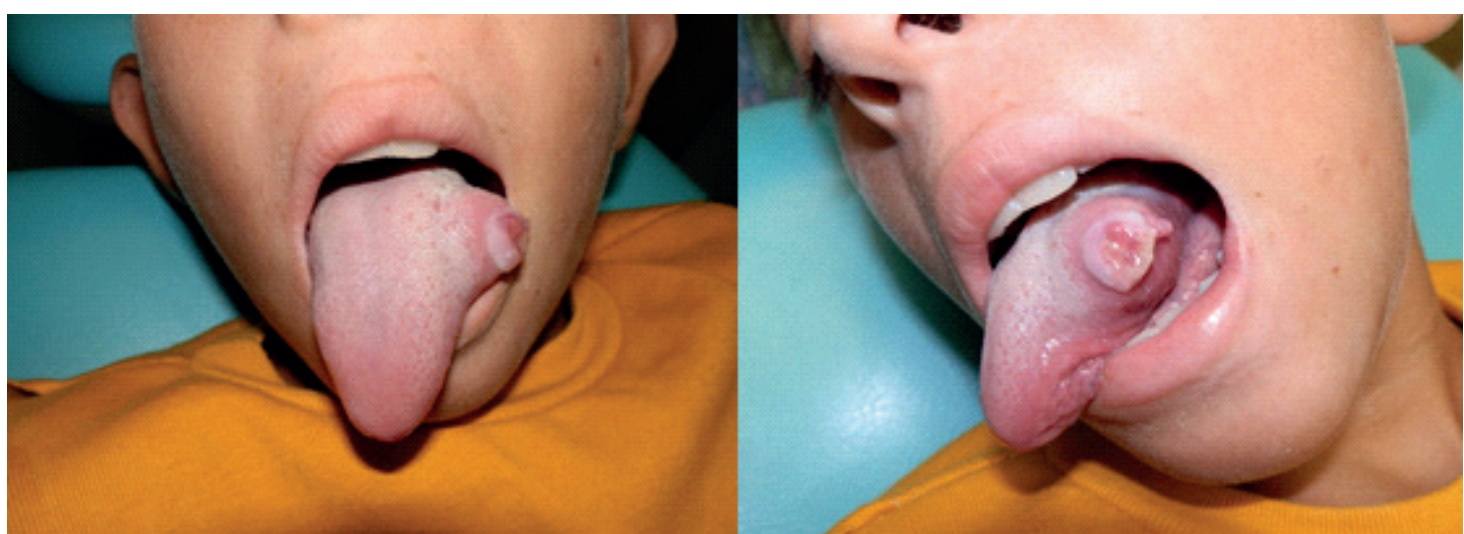

Figure 1. Clinical image of tumoral lesion in left lateral border of tongue.

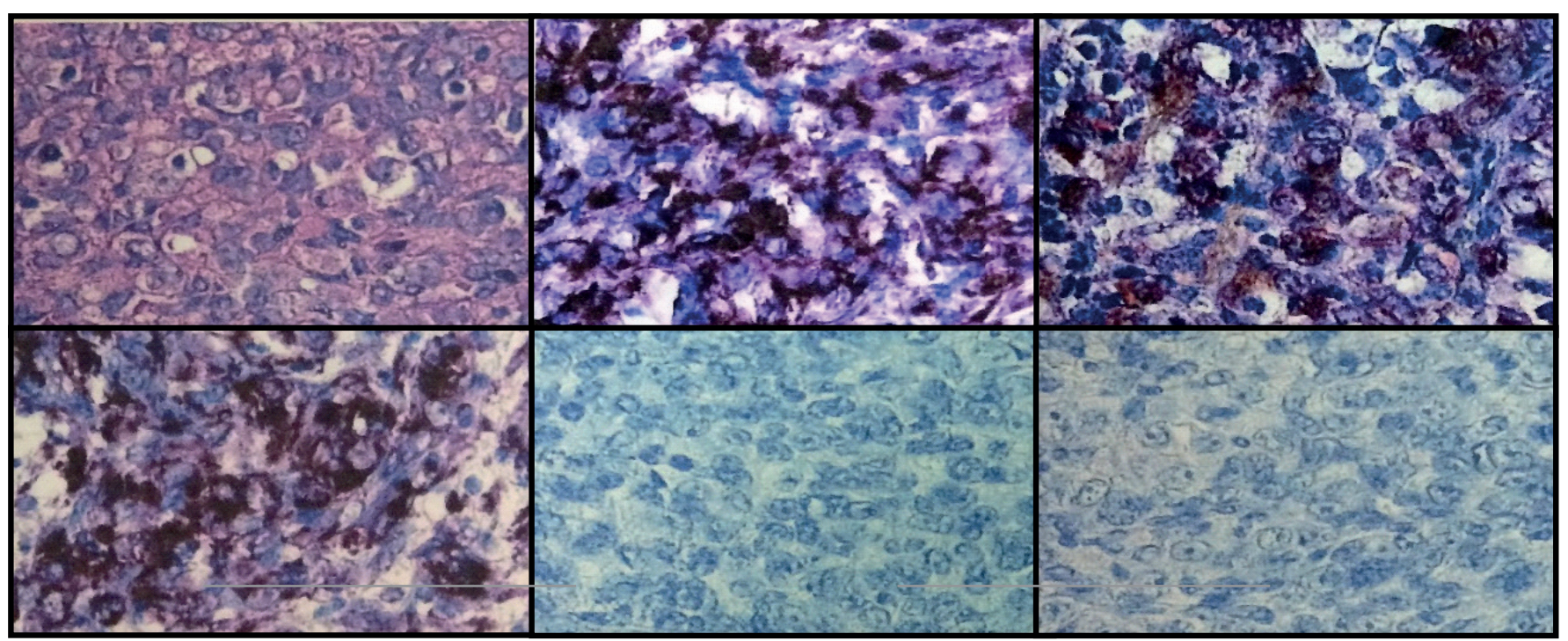

Figure 2. 400X micrograph: H\&E staining showing blue round cells with different sizes and pleomorphic and hipercromatic nuclei (A). Positive inmuno staining: Vimentin (B). Neuron-specific neuroendocrine-enolase differentiation (C). CD99 / MIC-2 (D). Negative inmuno staining: Desmin (E). Common leucocitary antigen (F).

computed tomography of the neck, thorax, abdomen and pelvis, in which no contributory findings were evidenced. In addition, an aspiration and biopsy of bone marrow was carried out, whose result reported normocellularity, with no alterations or neoplastic infiltrations. Once admitted by the Pediatric Oncology service, the patient underwent 4 cycles of chemotherapy, and seeing that the size of the lesion decreased significantly, a complete excision of the tumor with surgical margins was performed by the Oncology and Oral Maxillofacial Surgery team. Negative margins were reported in the histopathological study of the surgical piece. Currently, signs of disease or recurrence have not been observed in the patient (figure 3). Prior to the various studies and procedures carried out, the patient's legal guardian voluntarily signed an informed consent in which the possible risks and complications that could arise during the diagnostic process were explained, as well as the purpose and benefits of his contribution to the research.

\section{DISCUSSION}

The extra osseous Ewing's sarcoma (EOES) is a malignant tumor of soft mesenchymal tissue that usually 


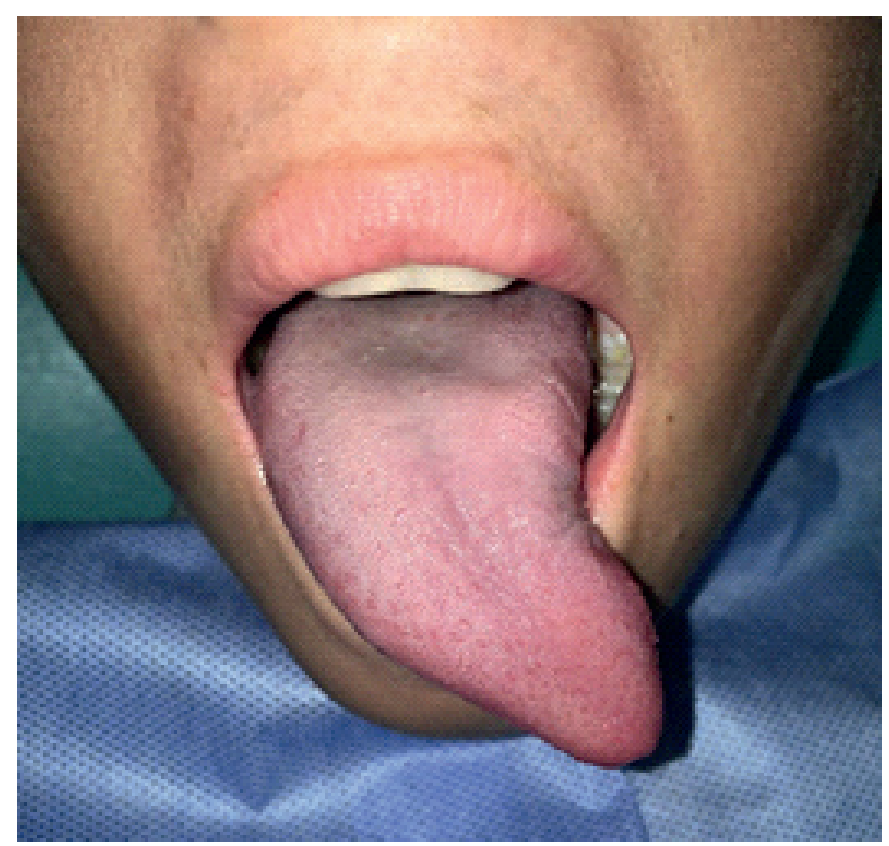

Figure 3. Post operatory clinical image after surgical removal of the lesion.

affects the lower extremities and the paravertebral region. This tumor has a very low incidence and represents approximately $1.1 \%$ of malignant soft tissue tumors. Within these, only 6 to $11 \%$ are found in the head and neck, so its appearance in this area is a highly relevant variant $[3,6]$. In agreement with this case, the age range of appearance of this tumor is between 5-25 years in any of its locations. Ewing's sarcoma is more prevalent in men than in women when all locations of the tumor are considered. Some publications report a male predominance of between 1.4: 1 and 2.4: 1 in cases of head and neck, coinciding with this case. However, recent studies establish a relatively balanced gender distribution, with only a very slight female predominance of 1.05: 1 in cases of Ewing's sarcoma in the oral cavity [3].

The exact etiology of this tumor remains unknown, however it is currently described histologically as a tumor of neuroectodermal origin [3]. Hematoxylin-eosin staining $(H$ \& E) reveals an intense blue color that defines the Ewing's sarcoma (ES) as belonging to the group of blue round cell tumors. Therefore, immunohistochemistry is an essential study for the differential diagnosis of this entity; in this case, the marker CD99 / MIC2, identified by antibody 013, was found positive, this marker is a cell membrane glycoprotein found in all ES and PNET, being reported in $98 \%$ of the cases [7].
The CD99 / MIC-2 marker has also been detected in other blue round cell tumors such as lymphoblastic lymphoma, rhabdomyosarcoma, small cell carcinoma and poorly differentiated synovial sarcoma [6], but in this case the possibility of another blue round cell tumor can be ruled out, due to the immunoreactive negativity to markers like leukocyte common antigen (CD45 / LCA), desmin and broad spectrum cytokeratin. Other immunohistochemical markers found to be negative were the epithelial membrane antigen (EMA), CD20 / L26, CD45-RO / UCHL-1 and terminal deoxynucleotidyl transferase (TDT).

The presence in tongue of this tumor is a very rare finding, taking into account that in the bibliographic review carried out, very little information was found regarding the extra osseous presentation in the head and neck region of this tumor and even less in this location. Therefore, a specific clinical description of this tumor in the tongue, was not found. The symptoms and characteristics of this sarcoma vary depending on the site of origin of the tumor. In the present case, a mass with indurated consistency with bounded edges was found, covered by whitish mucosa with ulcerated and painful areas, which was treated with chemotherapy and surgery. Over the years, several therapeutic modalities have been developed, previously the treatment of this tumor consisted only on radiotherapy and surgery and was associated with a very low survival rate; however, with the implementation of neoadjuvant chemotherapy, the prognosis of this disease radically changed. Early and reliable diagnosis, along with surgical excision and modern chemotherapy and / or radiotherapy, have greatly improved the prognosis of this tumor and therefore the survival rate of these patients $[6,8]$.

Some authors suggest that the response of this tumor to treatment and its prognosis is directly related to the characteristics of the tumor and the age of the patient and is not determined by the tissue component, which means regardless of whether it is a bone or extraosseous Ewing's sarcoma. However, recent studies indicate that although the prognostic factors of EOES seem to be similar to osseous ES, the prognosis of this tumor in soft tissue is more favorable than in bone tissue and even more in cases of localized tumors, since it is estimated that the overall 5-year survival rate is superior in cases of localized EOES compared to localized skeletal tumors, which could explain the good evolution and response to treatment in this patient $[7,8]$. 


\section{CONCLUSION}

Ewing's sarcoma is a malignant tumor with aggressive behavior, so this case represents a finding of clinical and epidemiological relevance, both due to its extra-osseous appearance and unusual behavior.

\section{COLLABORATORS}

N CHAPARRO, A DÍAZ, L HERRERA, R PINEDA, B PEROZO and $B$ ALVAREZ, acquisition, analysis or interpretation of research data; writing and reviewing the document in Spanish and English; approval of the final version to be published.

\section{REFERENCES}

1. Huang L, Chen X, Li L. Image and pathological features of Ewing's sarcoma in the oral and maxillofacial region. Zhong Nan Da Xue Xue Bao Yi Xue Ban. 2016;41(6):637-43. https:// doi.org/10.11817/j.issn.1672-7347.2016.06.014

2. Uribe J, Palomera H, Olvera J, Alcántara L, Zambrano L, Gómez E, et al. Sarcoma de Ewing extraóseo. Bol Med Hosp Infant Mex. 2013;70(6):477-81.
3. Margaix-Muñoz M, Bagán J, Poveda-Roda R. Ewing sarcoma of the oral cavity. A review. J Clin Exp Dent. 2017;9(2):e294-e301. https://doi.org/10.4317/jced.53575

4. Subbiah $V$, Kurzrock R. Ewing's sarcoma: overcoming the therapeutic plateau. Discov Med. 2012;13(73):405-15.

5. Hernández E, Mosquera G, Quintero O, Hernández I. Sarcoma de Ewing. AMC. 2013;17(5):623-40.

6. Kang MS, Yoon HK, Choi JB, Eum JW. Extraskeletal Ewing's sarcoma of the hardpalate. J Korean Med Sci. 2005;20(4):687-90.

7. Galyfos G, Karantzikos GA, Kavouras N, Sianou A, Palogos K, Filis K. Extraosseous Ewing sarcoma: diagnosis, prognosis and optimal management. Indian J Surg. 2016;78(1):49-53. https://doi.org/10.1007/s12262-015-1399-0

8. Pradhan A, Grimer RJ, Spooner D, Peake D, Carter SR, Tillman RM et al. Oncological outcomes of patients with Ewing's sarcoma: is there a difference between skeletal and extra-skeletal Ewing's sarcoma?. J Bone Joint Surg Br. 2011Apr;93(4):531-6. https://doi.org/10.1302/0301-620X.93 B4.25510

Received on: 18/4/2018 Final version resubmitted on: 17/5/2018 Approved on: 13/6/2018 